\section{Workers Memorial Day - April 28, 2017}

Workers Memorial Day, observed annually on April 28, ${ }^{*}$ recognizes workers who suffered or died because of exposures to hazards at work. In 2015, work-related injuries claimed the lives of 4,836 U.S. workers. ${ }^{\dagger}$ Although deaths resulting from work-related injuries are captured by surveillance systems, most deaths resulting from work-related illness are not. In 2007, an estimated 53,445 persons died from work-related illness (1). In 2015, employers reported approximately 2.9 million nonfatal injuries and illnesses to private industry workers and 752,600 to state and local government workers $\$$; an emergency department surveillance system estimates that 2.7 million workers were treated for work-related injuries in emergency departments, resulting in 85,000 hospitalizations (National Institute for Occupational Safety and Health [CDC-NIOSH], unpublished data, 2017).

Occupational injuries and illnesses also have economic costs. The societal cost of work-related fatalities, injuries, and illnesses was estimated at $\$ 250$ billion in 2007 , based on methods that focus on medical costs and productivity losses (1).

New data on fatal falls in the oil and gas industry are reported in this issue of MMWR. CDC-NIOSH collects detailed information about these fatal events in its Fatalities in Oil and Gas Extraction Industry database (https://www. cdc.gov/niosh/topics/fog/about.html) and uses these data to inform the industry and other stakeholders about health and safety risks and to guide intervention activities.

*Workers Memorial Day was established in 1970 by the American Federation of Labor and Congress of Industrial Organizations.

${ }^{\dagger}$ National Census of Fatal Occupational Injuries in 2015. https://www. bls.gov/news.release/pdf/cfoi.pdf.

$\$$ Employer-reported workplace injuries and illnesses in 2015. https://www. bls.gov/news.release/pdf/osh.pdf.

\section{Reference}

1. Leigh JP. Economic burden of occupational injury and illness in the United States. Milbank Q 2011;89:728-72. https://doi. org/10.1111/j.1468-0009.2011.00648.x

\section{Occupational Fatalities Resulting from Falls in the Oil and Gas Extraction Industry, United States, 2005-2014} Krystal L. Mason, ScM ${ }^{1}$; Kyla D. Retzer, $\mathrm{MPH}^{1}$; Ryan Hill, $\mathrm{MPH}^{2}$;
Jennifer M. Lincoln, $\mathrm{PhD}^{1}$

During 2003-2013, fatality rates for oil and gas extraction workers decreased for all causes of death except those associated with fall events, which increased $2 \%$ annually during 2003-2013 (1). To better understand risk factors for these events, CDC examined fatal fall events in the oil and gas extraction industry during 2005-2014 using data from case investigations conducted by the Occupational Safety and Health Administration (OSHA). Sixty-three fatal falls were identified, accounting for $15 \%$ of all fatal events. Among fatal falls, 33 $(52 \%)$ workers fell from a height of $>30$ feet ( 9 meters), and 22 (35\%) fell from the derrick board, the elevated work platform located in the derrick (structure used to support machinery on a drilling rig). Fall fatalities occurred most frequently when drilling rigs were being assembled or disassembled at the well site (rigging up or rigging down) $(14 ; 22 \%)$ or when workers were removing or inserting drill pipe into the wellbore $(14 ; 22 \%)$. Measures that target derrickmen and workers engaged in assembling and disassembling drilling rigs (rigging up and down) could reduce falls in this industry. Companies should annually update their fall protection plans and ensure

\section{INSIDE}

422 Trends in Repeat Births and Use of Postpartum Contraception Among Teens — United States, 2004-2015

427 Announcements

429 QuickStats

Continuing Education examination available at https://www.cdc.gov/mmwr/cme/conted_info.html\#weekly.

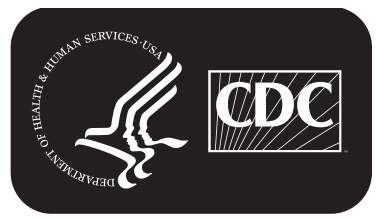

